\title{
A (110) Facet-Dominated Vanadium Dioxide Enabling Bidirectional Electrocatalysis for Lithium-Sulfur Batteries
}

Zhihao Yu $u^{1}$, Wei Lv $v^{2}$, Qiaowei Lin $^{2}$, Xiehe Huang ${ }^{1}$, Ying Yang ${ }^{1 *}$

${ }^{1}$ State Key Laboratory of Control and Simulation of Power System and Generation

Equipments, Tsinghua University, Beijing 100084, China

2 Shenzhen Key Laboratory for Graphene-Based Materials, Tsinghua Shenzhen International Graduate School, Shenzhen 518055, China

\$Zhihao Yu and Wei Lv contributed equally to this work.

*Corresponding author:

Email address: yingyang@tsinghua.edu.cn 

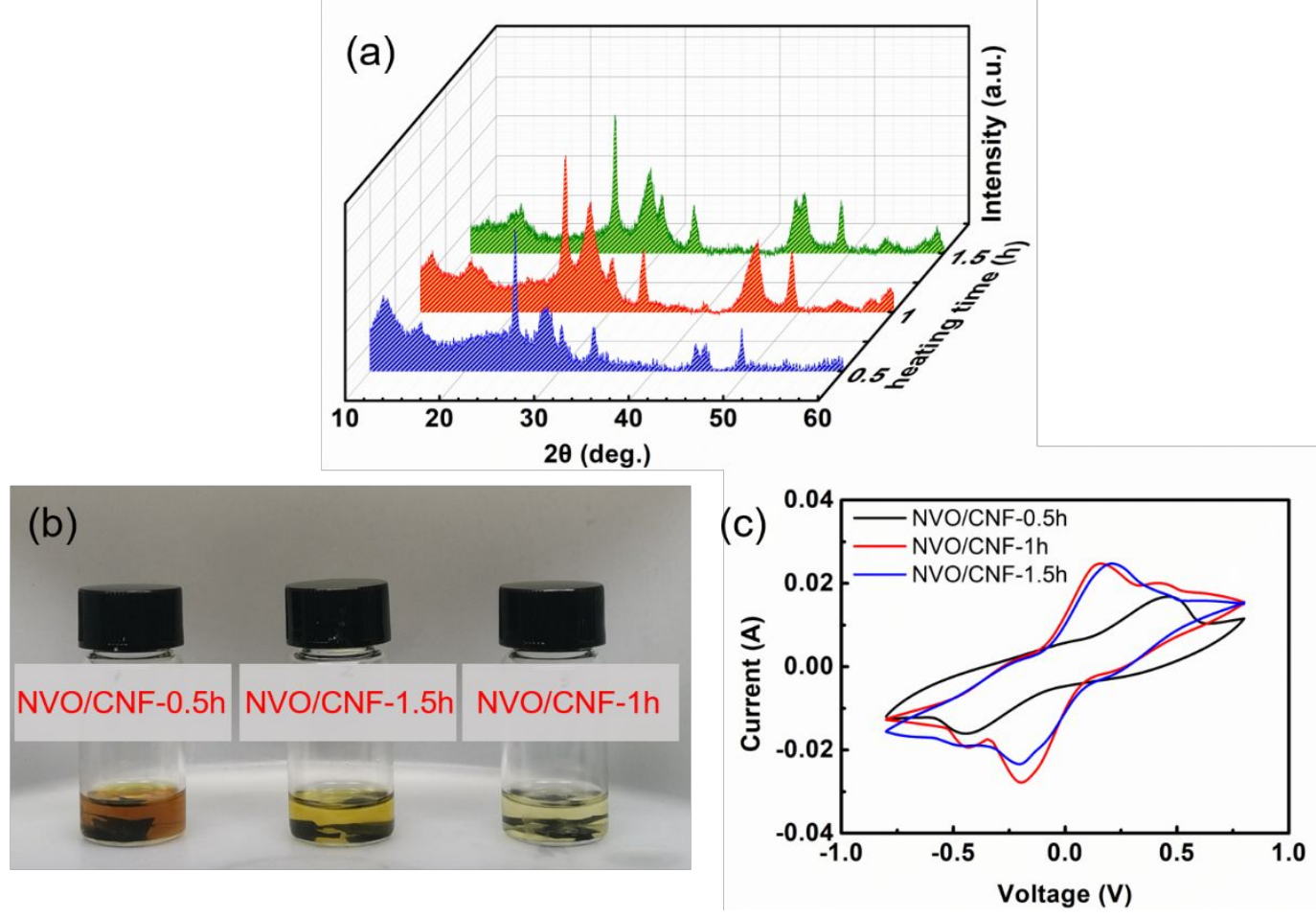

Figure S1. (a) The XRD patterns of NVO/CNF treated with different heating times $(0.5$, 1, and $1.5 \mathrm{~h}$ ); (b) Photos of $\mathrm{Li}_{2} \mathrm{~S}_{6}$ adsorption measurements using NVO/CNF-0.5h, NVO/CNF-1h, and NVO/CNF-1.5h; (c) The CV profiles of $\mathrm{Li}_{2} \mathrm{~S}_{6}$ symmetric cells at a scan rate of $50 \mathrm{mV} \mathrm{s}^{-1}$ using NVO/CNF-0.5h, NVO/CNF-1h and NVO/CNF-1.5h loaded on CPs as electrodes.

The XRD patterns of NVO/CNF samples which were treated with different heating times of $0.5,1$ and $1.5 \mathrm{~h}$ (donated as NVO/CNF-0.5h, NVO/CNF-1h, NVO/CNF-1.5h) proved the coexistence of both monoclinic NVO and monoclinic $\mathrm{VO}_{2}(\mathrm{~B})$. With the increase of heating time, the characteristic peaks of $\mathrm{NVO}$ at $\sim 10^{\circ}$ and $40^{\circ}$ were weakened, indicating the decreased proportion of NVO due to the thermal decomposition. The visualized adsorption tests for NVO/CNF-0.5h, NVO/CNF-1h and $\mathrm{NVO} / \mathrm{CNF}-1.5 \mathrm{~h}$ towards $\mathrm{Li}_{2} \mathrm{~S}_{6}$ were conducted for $30 \mathrm{~min}$, as shown in Figure $\mathrm{S} 1 \mathrm{~b}$, showing the NVO/CNF-1h had the stronger adsorption ability. The CV profiles of $\mathrm{Li}_{2} \mathrm{~S}_{6}$ symmetric cells assembled using NVO/CNF-0.5h, NVO/CNF-1h and NVO/CNF-1.5h 
loading on the CPs as electrodes further showed the different catalytic activities. For the NVO/CNF-1h electrodes, two pairs of redox peaks were observed with the smallest peak separation, suggesting it can effectively promote the redox reactions of LiPSs than the other two samples. Thus, the $1 \mathrm{~h}$ heat treatment was used in the following preparation process.

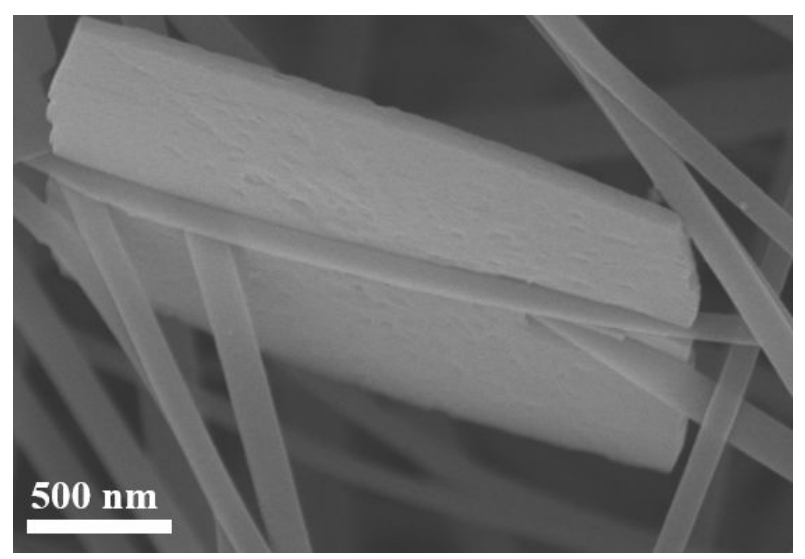

Figure S2. SEM image of the NVO/CNF

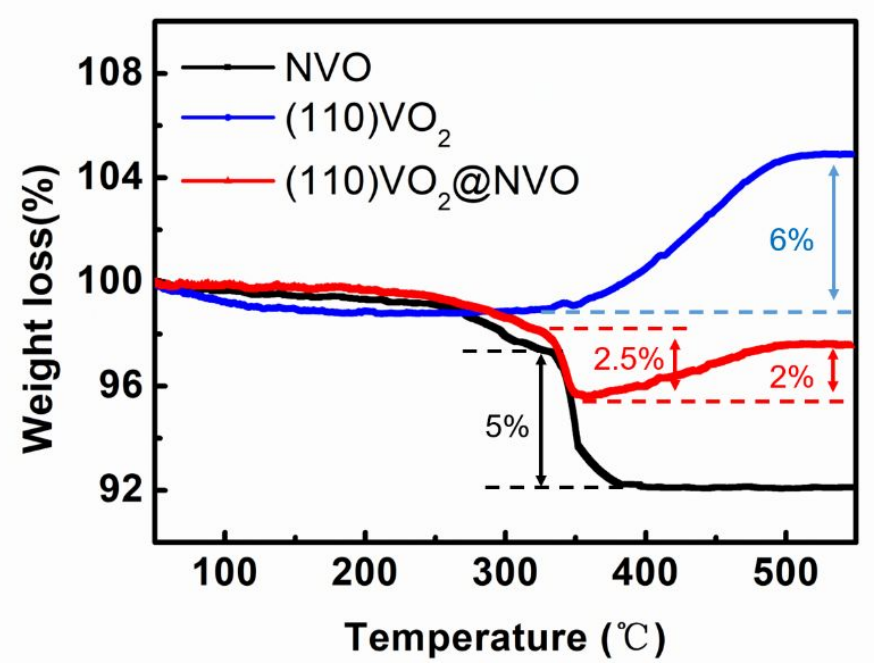

Figure S3. Thermogravimetric analysis of $\mathrm{NVO},(110) \mathrm{VO}_{2}$, and (110) $\mathrm{VO}_{2} @ \mathrm{NVO} / \mathrm{CNF}$

During the temperature of $\sim 340{ }^{\circ} \mathrm{C}$, the weight loss of $\sim 5 \%$ in the TGA curve of NVO can be ascribed to the decomposition of the ammonium salt according to the equation:

$$
\left(\mathrm{NH}_{4}\right)_{2} \mathrm{~V}_{4} \mathrm{O}_{9}+\mathrm{O}_{2} \rightarrow \mathrm{V}_{2} \mathrm{O}_{5}+2 \mathrm{NH}_{3}+\mathrm{H}_{2} \mathrm{O}
$$


$\mathrm{VO}_{2}$ undergoes a direct oxidation process into $\mathrm{V}_{2} \mathrm{O}_{5}$ at higher than $360^{\circ} \mathrm{C}$ with a weight increase of $\sim 6 \%$. According to the decomposition and oxidation process, the (110) $\mathrm{VO}_{2} @ \mathrm{NVO}$ composites present a weight loss of 2.5\% and a followed weight increase of 2\%. Thus, the mass ratio of NVO:(110) $\mathrm{VO}_{2}$ in $(110) \mathrm{VO}_{2} @ \mathrm{NVO}$ can be calculated to be $\sim 1.5: 1$.
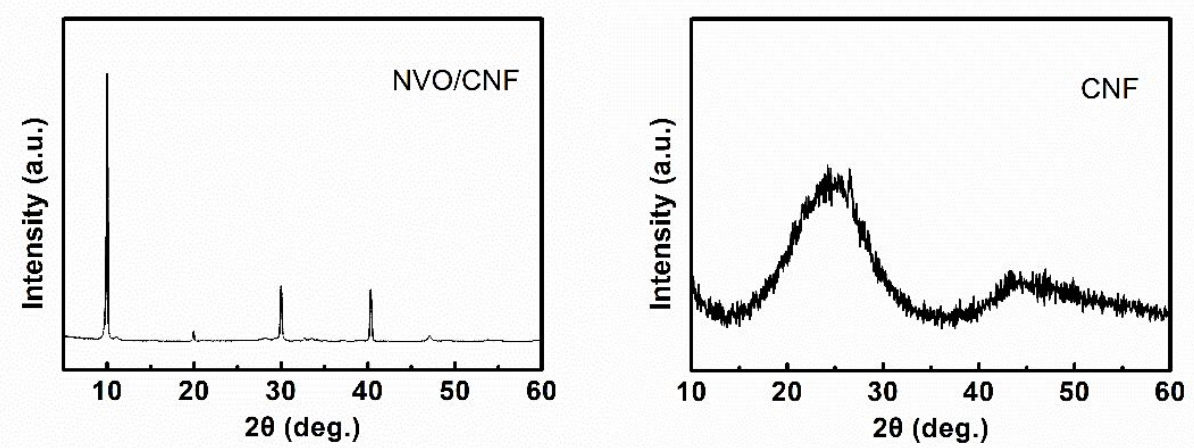

Figure S4. The XRD patterns of NVO/CNF and CNF

The peaks at $\sim 24^{\circ}$ and $44^{\circ}$ can be ascribed to the (002) and (10) characteristic peaks of carbon (Figure S4). The low intensity and broad half-peak width of002 peak indicate the disorder carbon structure with low crystallinity for the prepared CNF. 

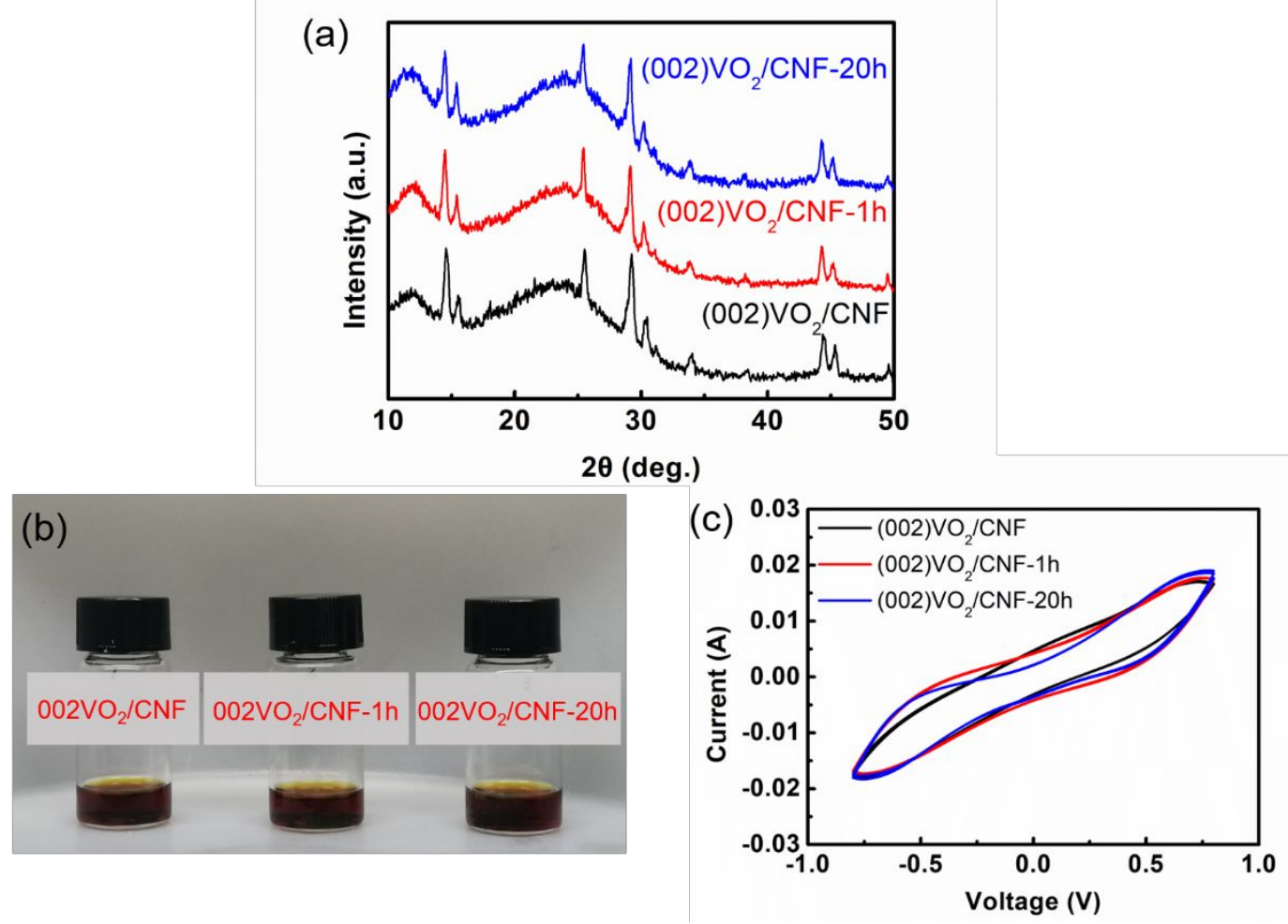

Figure S5. (a) XRD patterns of $(002) \mathrm{VO}_{2} / \mathrm{CNF}, \quad(002) \mathrm{VO}_{2} / \mathrm{CNF}-1 \mathrm{~h}$ and (002) $\mathrm{VO}_{2} / \mathrm{CNF}-20 \mathrm{~h}$; (b) digital photo of $\mathrm{Li}_{2} \mathrm{~S}_{6}$ solution with $(002) \mathrm{VO}_{2} / \mathrm{CNF}$, (002) $\mathrm{VO}_{2} / \mathrm{CNF}-1 \mathrm{~h}$, and $(002) \mathrm{VO}_{2} / \mathrm{CNF}-20 \mathrm{~h}$ for $30 \mathrm{~min}$; (c) CV profiles of $\mathrm{Li}_{2} \mathrm{~S}_{6}$ symmetric cells at a scan rate of $50 \mathrm{mV} \mathrm{s}^{-1}$ using (002) $\mathrm{VO}_{2} / \mathrm{CNF},(002) \mathrm{VO}_{2} / \mathrm{CNF}-1 \mathrm{~h}$ and $(002) \mathrm{VO}_{2} / \mathrm{CNF}-20 \mathrm{~h}$ as electrodes

The XRD patterns of (002) $\mathrm{VO}_{2} / \mathrm{CNF}$ with the heat treatment at $400{ }^{\circ} \mathrm{C}$ for $1 \mathrm{~h} / 20 \mathrm{~h}$ (donated as $\left.(002) \mathrm{VO}_{2} / \mathrm{CNF}-1 \mathrm{~h},(002) \mathrm{VO}_{2} / \mathrm{CNF}-20 \mathrm{~h}\right)$ were shown in Figure S5a. The crystallinities of $\mathrm{VO}_{2}$ in $(002) \mathrm{VO}_{2} / \mathrm{CNF},(002) \mathrm{VO}_{2} / \mathrm{CNF}-1 \mathrm{~h}$, and (002) $\mathrm{VO}_{2} / \mathrm{CNF}-20 \mathrm{~h}$ are similar, which can be proved by the negligible differences on the XRD peaks. The $\mathrm{Li}_{2} \mathrm{~S}_{6}$ adsorption ability measurements of (002) $\mathrm{VO}_{2} / \mathrm{CNF},(002) \mathrm{VO}_{2} / \mathrm{CNF}-1 \mathrm{~h}$, and (002) $\mathrm{VO}_{2} / \mathrm{CNF}-20 \mathrm{~h}$ also presented similar adsorption abilities. The $\mathrm{CV}$ profiles of $\mathrm{Li}_{2} \mathrm{~S}_{6}$ symmetric cells at a scan 
rate of $50 \mathrm{mV} \mathrm{s}^{-1}$ using those samples as electrodes are performed as shown in Figure S5c, which also reveal that the influence of the heating process on catalytic properties and performance can be neglected.

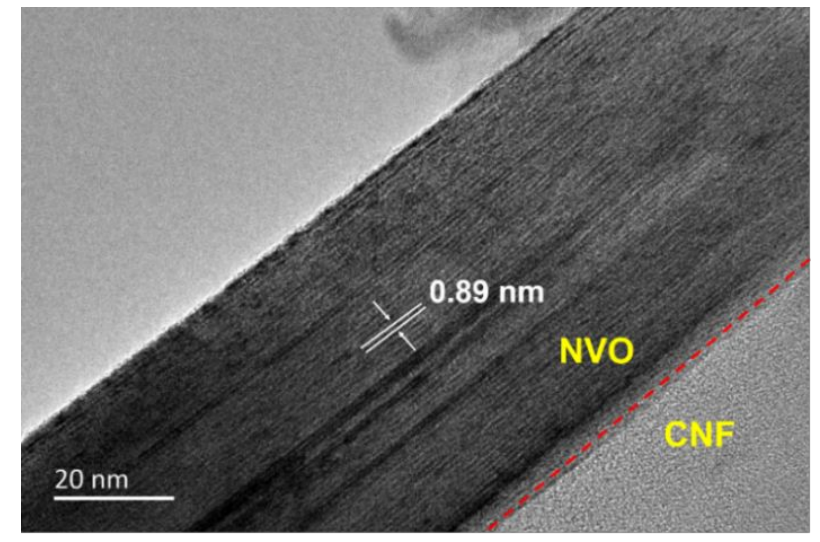

Figure S6. HRTEM image of NVO/CNF

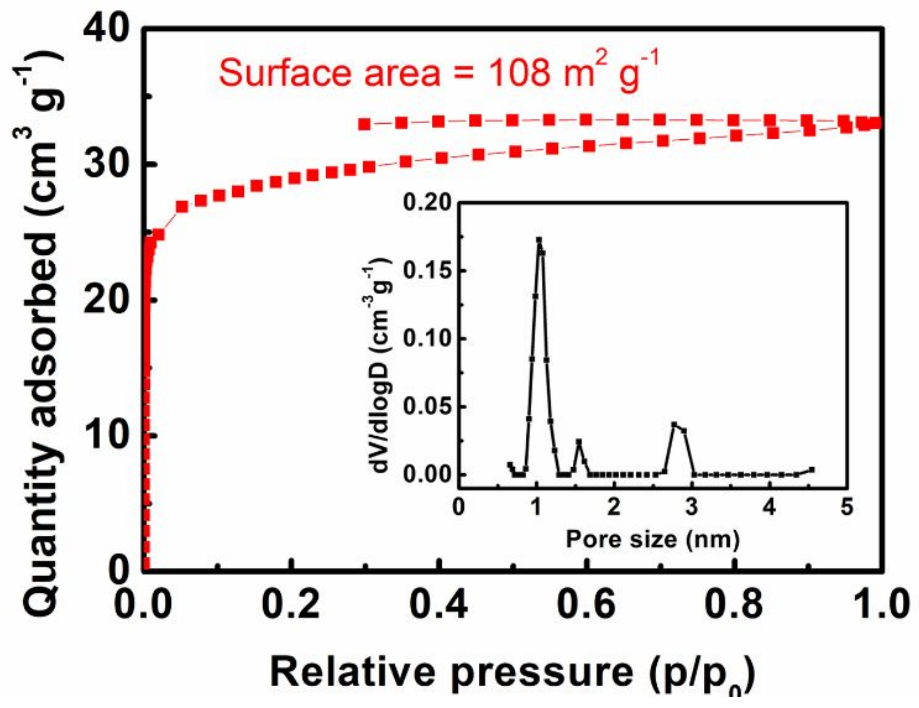

Figure S7. $\mathrm{N}_{2}$ adsorption/desorption isotherm and the inserted pore size distribution of (110) $\mathrm{VO}_{2} @ \mathrm{NVO} / \mathrm{CNF}$. 

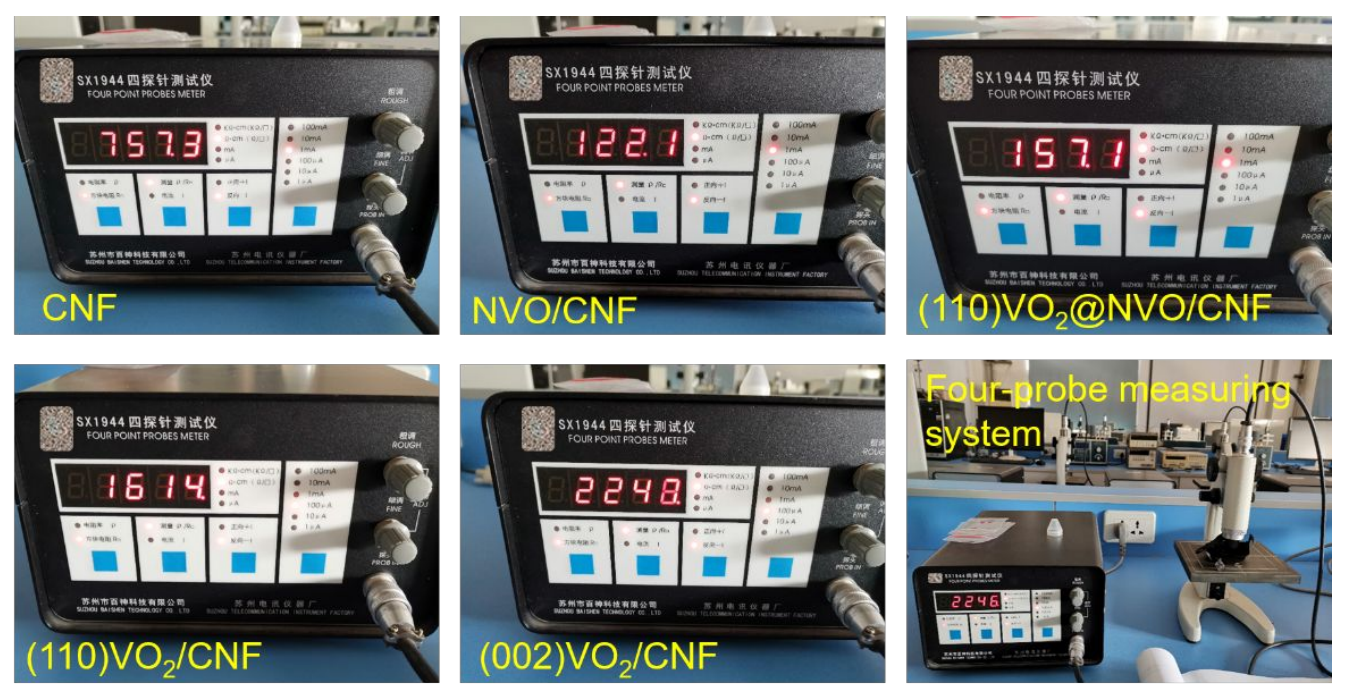

Figure S8. The digital photos of four-probe measurement (The logo have been blurred)
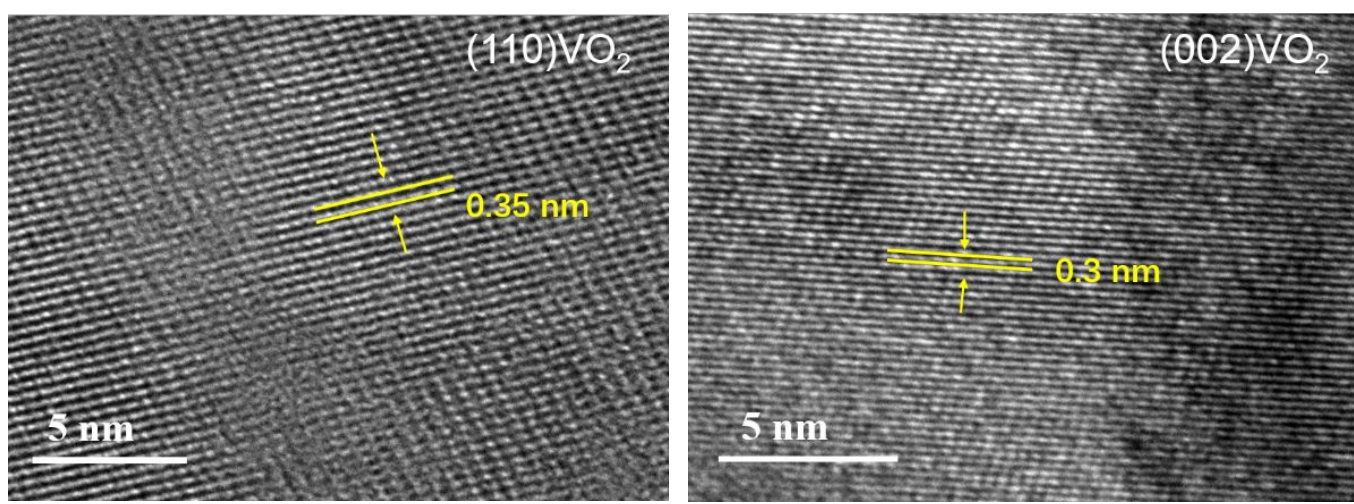

Figure S9. HRTEM images of (110) $\mathrm{VO}_{2}$ and $(002) \mathrm{VO}_{2}$

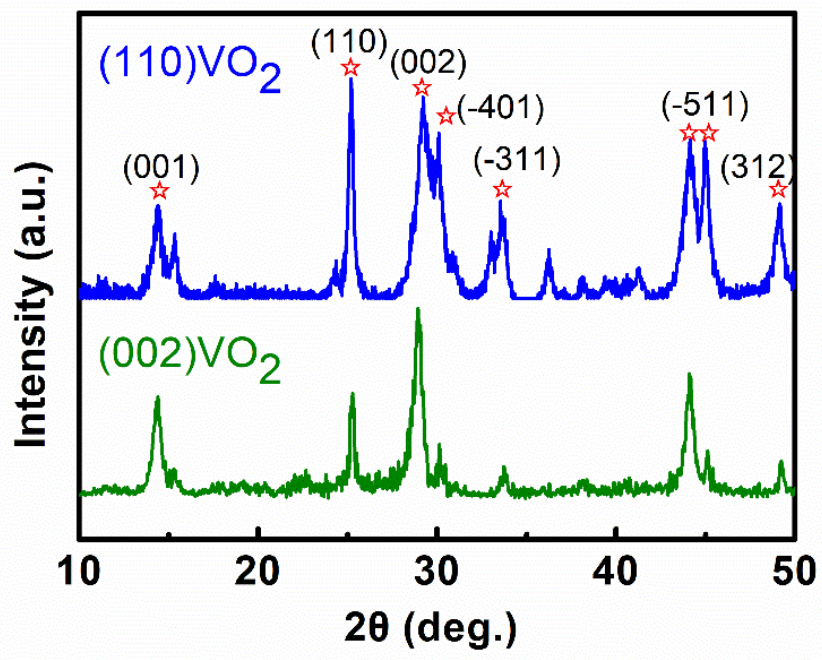

Figure S10. XRD patterns of $(110) \mathrm{VO}_{2}$ and $(002) \mathrm{VO}_{2}$ 

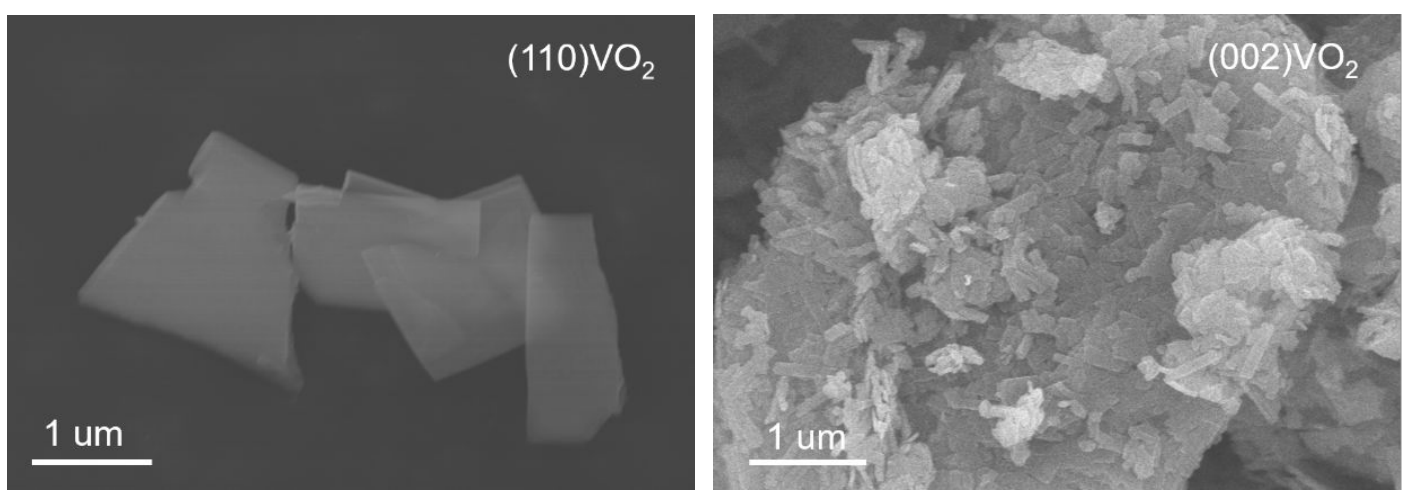

Figure $\mathrm{S} 11 . \mathrm{SEM}$ images of $(110) \mathrm{VO}_{2}$ and $(002) \mathrm{VO}_{2}$
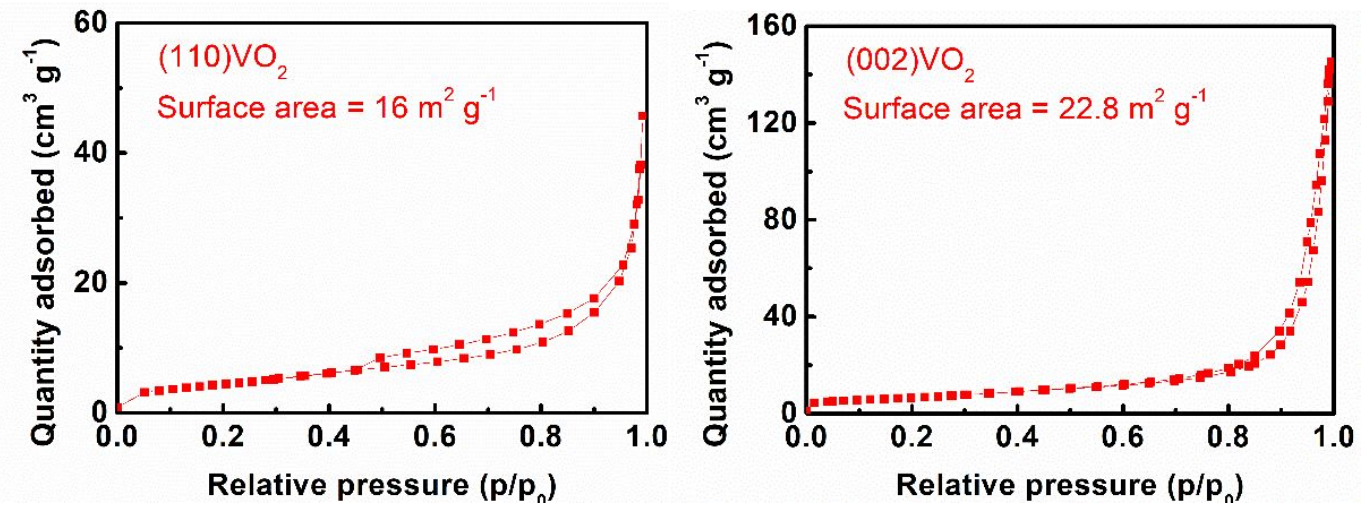

Figure $\mathrm{S} 12 . \mathrm{N}_{2}$ adsorption/desorption isotherm of (110) $\mathrm{VO}_{2}$ and $(002) \mathrm{VO}_{2}$

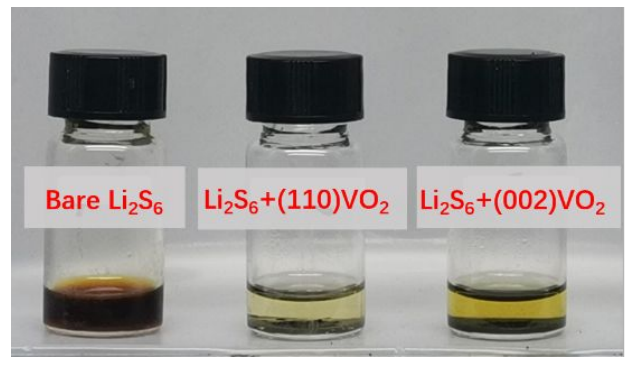

Figure $\mathrm{S} 13 . \mathrm{Li}_{2} \mathrm{~S}_{6}$ adsorption test of bare solution, with (110) $\mathrm{VO}_{2}$, with $(002) \mathrm{VO}_{2}$

A visualized adsorption test was employed in parallel by adding an identical amount of $(110) \mathrm{VO}_{2}$ and $(002) \mathrm{VO}_{2}$ into the $\mathrm{Li}_{2} \mathrm{~S}_{6}$ solution for 2 hour, respectively. (110) facet of $\mathrm{VO}_{2}$ presented a superior attraction toward soluble polysulfides based on the lightest color of the LiPSs solution (Fig. S13). 


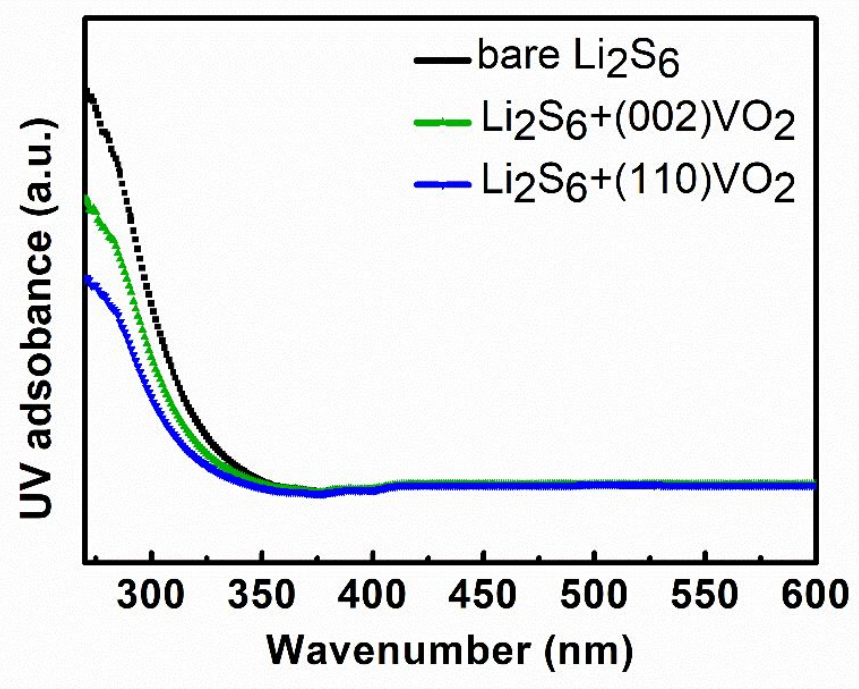

Figure S14. UV-vis absorption of $\mathrm{Li}_{2} \mathrm{~S}_{6}$ solution with (110) $\mathrm{VO}_{2}$ and $(002) \mathrm{VO}_{2}$
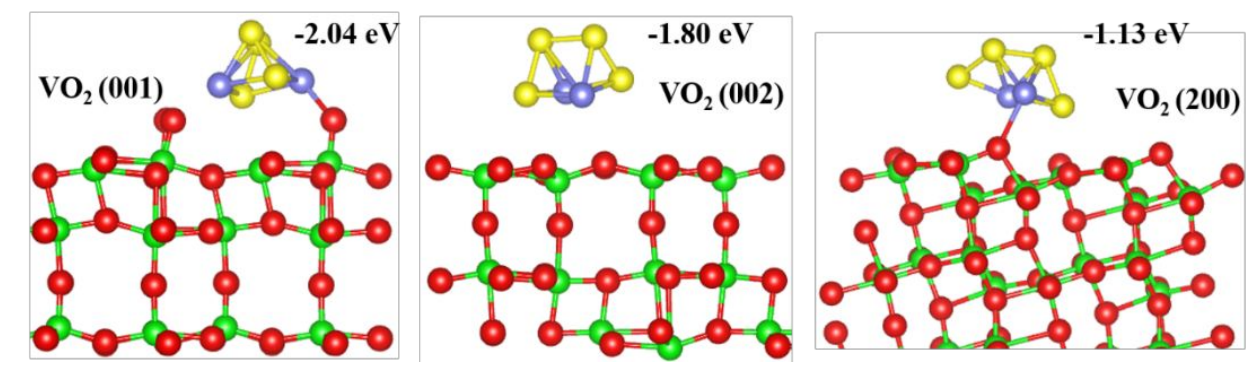

Figure S15. Optimized geometries of $\mathrm{Li}_{2} \mathrm{~S}_{4}$ on $\mathrm{VO}_{2}(001)$, (002) and (200) surfaces
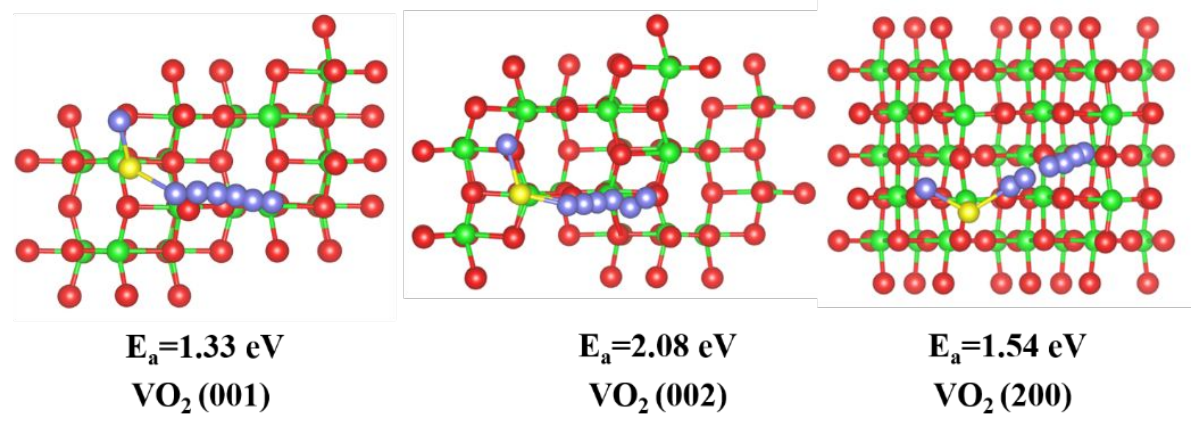

Figure S16. Decomposition pathways of $\mathrm{Li}_{2} \mathrm{~S}$ on different plane of $\mathrm{VO}_{2}(001),(002)$ and (200) surface 

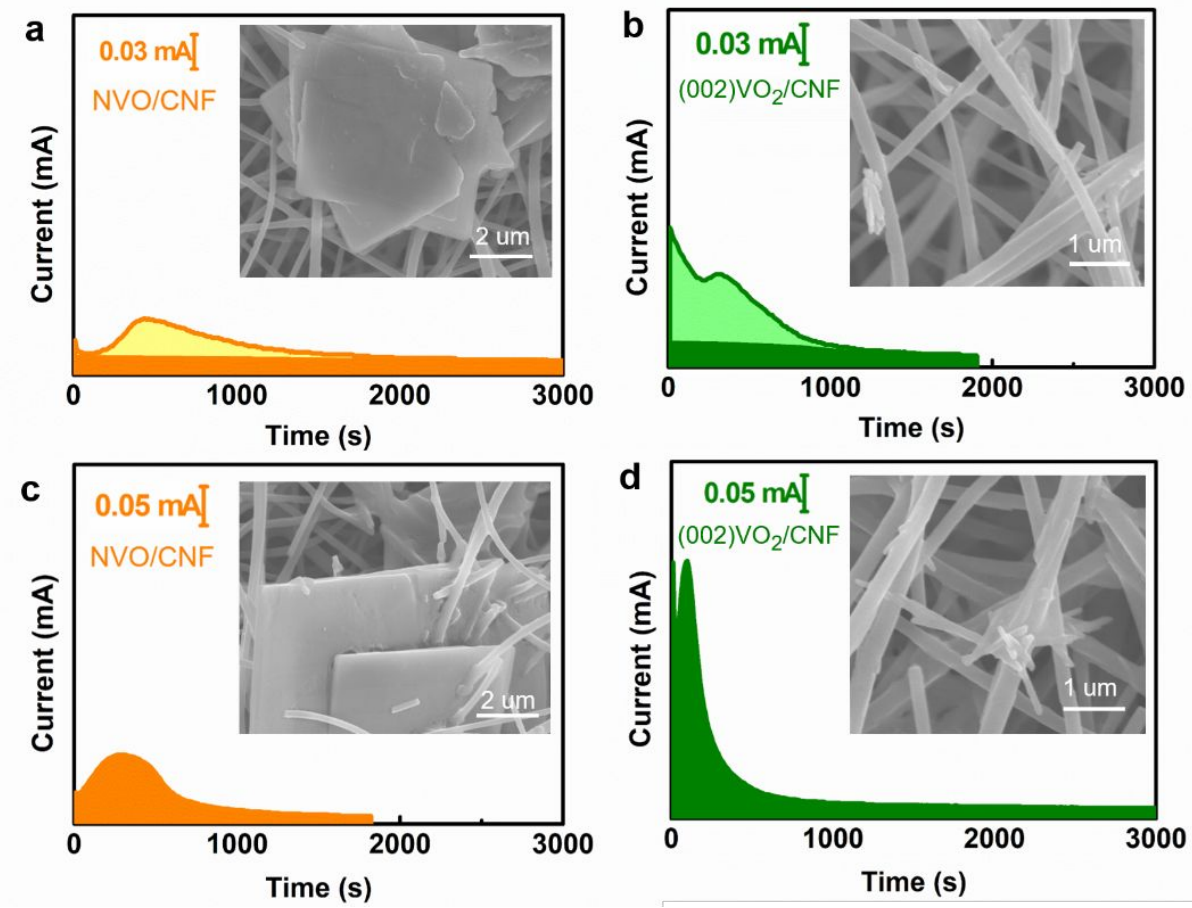

Figure S17. The $\mathrm{Li}_{2} \mathrm{~S}$ nucleation and dissolution experiments on surfaces of NVO/CNF, (002) $\mathrm{VO}_{2} / \mathrm{CNF}$. (a) and (b) Potentiostatic discharge profiles of $\mathrm{Li}_{2} \mathrm{~S}_{8}$ solution on different sanples at $2.05 \mathrm{~V}$; (c) and (d) Potentiostatic charge profiles on different samples at $2.35 \mathrm{~V}$. The insets are SEM figures presenting the morphology of $\mathrm{Li}_{2} \mathrm{~S}$ nucleation and dissolution on different surfaces.
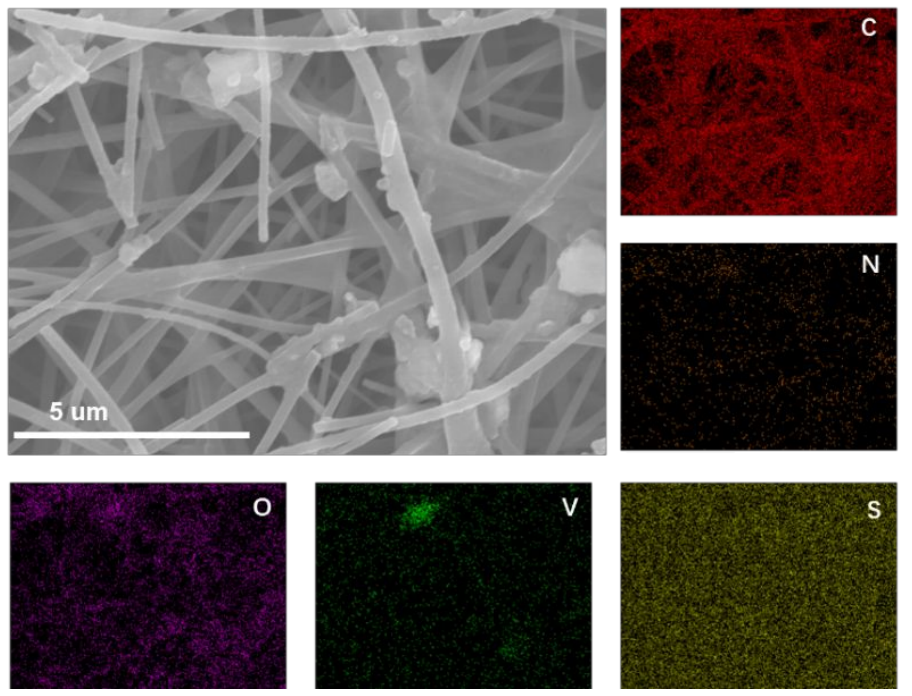

Figure S18. EDS mappings of $\mathrm{Li}_{2} \mathrm{~S}$ nucleation on (110) $\mathrm{VO}_{2} @ \mathrm{NVO} / \mathrm{CNF}$ 
a

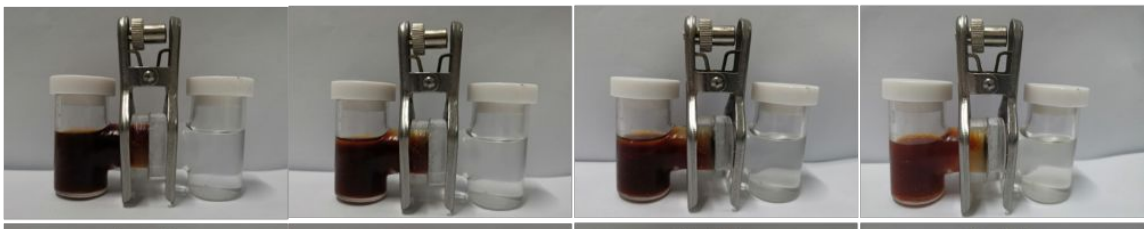

b

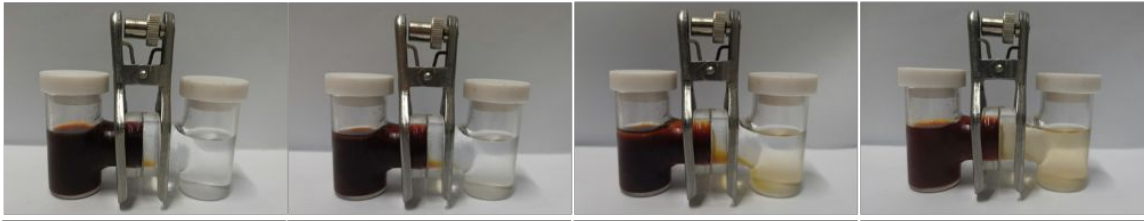

C

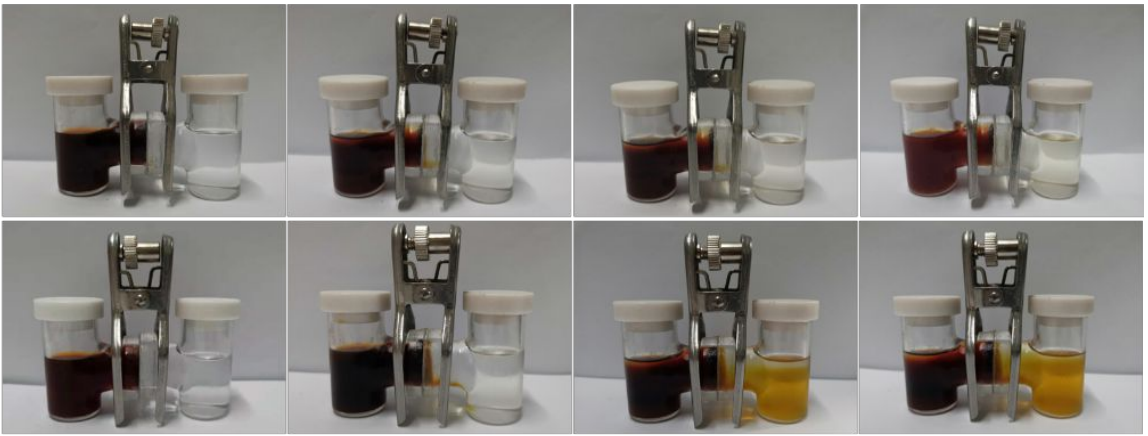

$\mathrm{Oh}$

$2 \mathrm{~h}$

$4 \mathrm{~h}$

$12 \mathrm{~h}$

Figure S19. H-cell-type LiPSs permeation test of (a) (110) $\mathrm{VO}_{2} / \mathrm{CNF}$, (b) NVO/CNF,

(c) (002) VO2/CNF, and (d) CNF for $12 \mathrm{~h}$.

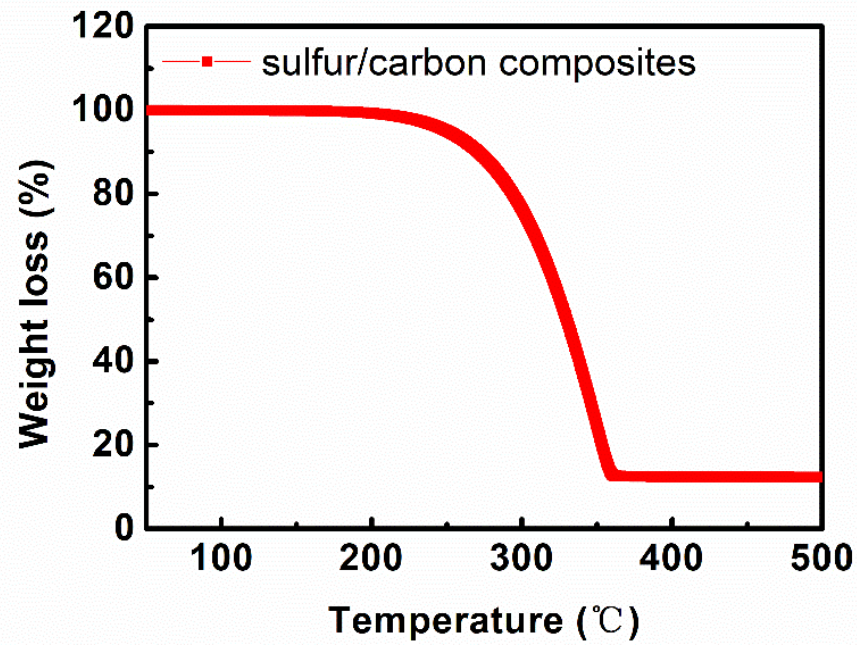

Figure S20. Thermogravimetric analysis of sulfur/carbon composites. 


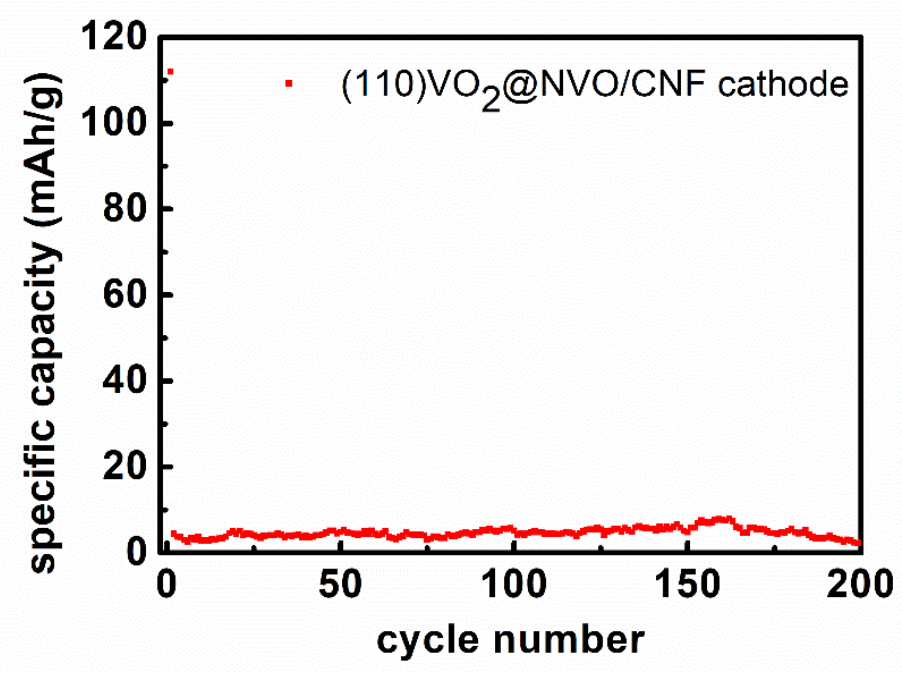

Figure S21. Cycle performance of cells with (110)VO $\mathrm{VO}_{2} @ \mathrm{NVO} / \mathrm{CNF}$ cathode

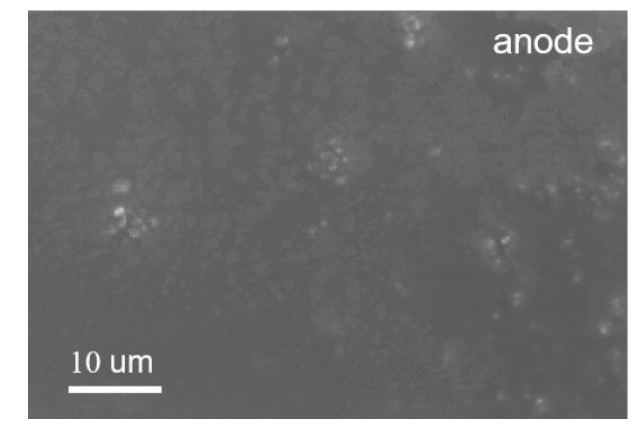

Figure S22. SEM images of cycled anode of Li-S battery with (110) $\mathrm{VO}_{2} @ \mathrm{NVO} / \mathrm{CNF}$ after 300 cycles at $0.1 \mathrm{C}$
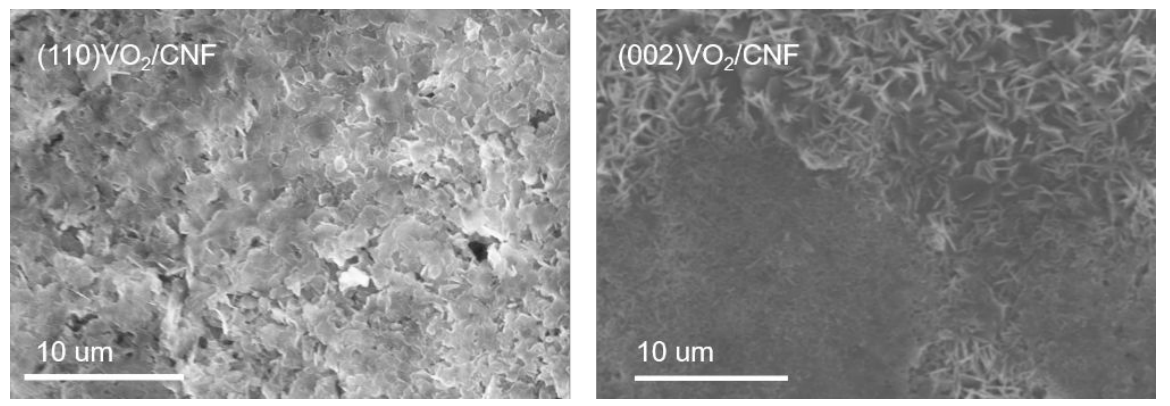

Figure S23. SEM morphology of cycled anode of Li-S battery with (110) $\mathrm{VO}_{2} / \mathrm{CNF}$ and $(002) \mathrm{VO}_{2} / \mathrm{CNF}$ interlayer after 300 cycles at $0.1 \mathrm{C}$ 


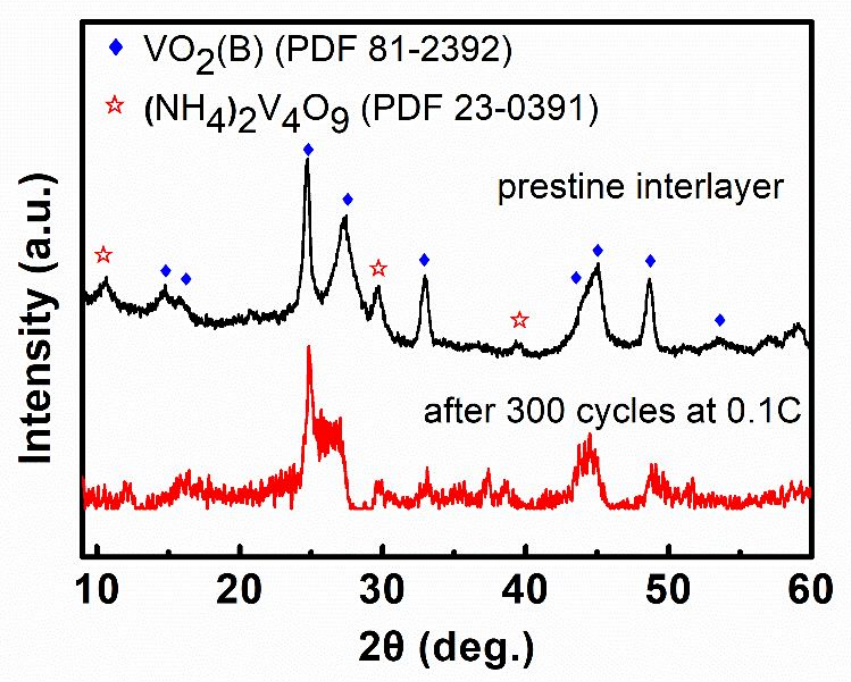

Figure S24. XRD patterns of (110) VO $\mathrm{VO}_{2} @ \mathrm{NVO} / \mathrm{CNF}$ before and after 300 cycles at $0.1 \mathrm{C}$.

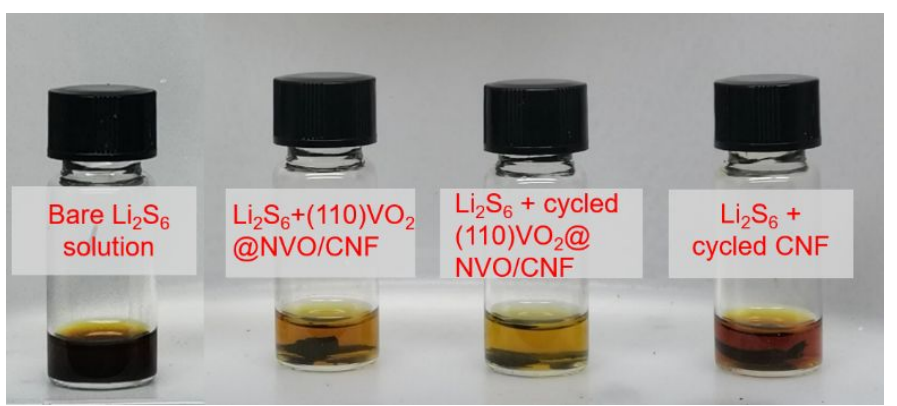

Figure S25. $\mathrm{Li}_{2} \mathrm{~S}_{6}$ adsorption tests for uncycled (110) $\mathrm{VO}_{2} @ \mathrm{NVO} / \mathrm{CNF}$, cycled (110) $\mathrm{VO}_{2} @ \mathrm{NVO} / \mathrm{CNF}$ and cycled $\mathrm{CNF}$ adding into bare $\mathrm{Li}_{2} \mathrm{~S}_{6}$ solution for 10 minutes. The cycled interlayer was dissembled from the Li-S cells charged at $2.8 \mathrm{~V}$.

Table $\mathrm{S} 1$ The S-S bond lengths of optimized $\mathrm{Li}_{2} \mathrm{~S}_{4}$ cluster on diverse lattice surfaces

\begin{tabular}{|c|c|c|c|c|c|}
\hline Bond length & Bare $\mathrm{Li}_{2} \mathrm{~S}_{4}$ & $\left(\begin{array}{lll}1 & 1 & 0\end{array}\right)$ & $\left(\begin{array}{lll}0 & 0 & 1\end{array}\right)$ & $\left(\begin{array}{lll}0 & 0 & 2\end{array}\right)$ & $\left(\begin{array}{lll}2 & 0 & 0\end{array}\right)$ \\
\hline $\mathrm{S}-\mathrm{S} 1 / \AA$ & 2.03 & 2.03 & 2.05 & 2.08 & 2.06 \\
\hline $\mathrm{S}-\mathrm{S} 2 / \AA$ & 2.37 & 3.27 & 2.20 & 2.11 & 2.14 \\
\hline $\mathrm{S}-\mathrm{S} 3 / \AA$ & 2.03 & 2.03 & 2.07 & 2.07 & 2.11 \\
\hline
\end{tabular}

Table S2 High-rate catalytic performance compared with other previous reported work

\begin{tabular}{|c|c|c|}
\hline & Cycle rate maximum & Areal capacity $\left(\mathrm{mAh} \mathrm{cm}^{-2}\right)$ \\
\hline This work & $\mathbf{5 C}$ & $\mathbf{1 . 4 4}$ \\
\hline
\end{tabular}




\begin{tabular}{|c|c|c|}
\hline $\mathrm{TiO}_{2}-\mathrm{Ti}_{2} \mathrm{C}$ & $5 \mathrm{C}$ & 0.6 \\
\hline $\mathrm{MoO}_{2}-\mathrm{Mo}_{3} \mathrm{~N}_{2}$ & $4 \mathrm{C}$ & 0.55 \\
\hline $\mathrm{VTe}_{2}-\mathrm{MgO}$ & $3 \mathrm{C}$ & 1.12 \\
\hline $\mathrm{VO}_{2}-\mathrm{G}$ & $3 \mathrm{C}$ & 1.2 \\
\hline $\mathrm{VS}_{2}$ & $5 \mathrm{C}$ & 0.8 \\
\hline $\mathrm{TiN}$ & $5 \mathrm{C}$ & 0.996 \\
\hline
\end{tabular}

